\title{
Students' Motivation in Learning Listening by Using YouTube: Case Study
}

\author{
Umi Quina Indah Wati Poeryono ${ }^{1}$, Yousef Bani Ahmad ${ }^{2}$, Sidik Indra Nugraha ${ }^{3}$ \\ ${ }_{1}^{1}$ (English Education Department, Singaperbangsa University of Karawang, Indonesia). \\ ${ }^{3}$ (English Education Department, Singaperbangsa University of Karawang, Indonesia). \\ ${ }^{2}$ (English Education Department, Singaperbangsa University of Karawang, Indonesia). \\ * Corresponding Author. E-mail: ${ }^{1}$ umi.quina17175@student.unsika.ac.id
}

\begin{tabular}{|l|l|l|}
\hline Receive: 13/05/2021 & Accepted: 23/08/2021 & Published: 01/10/2021 \\
\hline
\end{tabular}

\begin{abstract}
Motivation is a critical component in encouraging language learning. Gifted language learners might also underperform due to a lack of motivation. This study aims to determine what factors impact students' motivation to learn listening through YouTube. employing a case study, the experience of 8 Universities of Singaperbangsa Karawang students was gathered by means of questionnaire and interview. The findings enable students to strive to enhance their listening abilities and discover new vocabulary, as well as speed and comprehend pronunciation. Furthermore, giving audio and pictures on YouTube makes studying more engaging and allows students to memorize the words or phrases they hear. it seems that students' motivation in learning to listen using YouTube is influenced by factors in intrinsic and extrinsic motivation.
\end{abstract}

Keyword: Intrinsic Motivation, Extrinsic Motivation, Listening Skills, YouTube

\begin{abstract}
Abstrak
Motivasi adalah komponen penting dalam mendorong pembelajaran bahasa. Pembelajar bahasa berbakat mungkin dapat berkinerja buruk karena kurangnya motivasi. Penelitian ini bertujuan untuk mengetahui faktor-faktor apa saja yang mempengaruhi motivasi siswa belajar mendengarkan melalui YouTube. Dengan menggunakan studi kasus, pengalaman 8 mahasiswa Universitas Singaperbangsa Karawang dikumpulkan melalui angket dan wawancara. Temuan memungkinkan siswa untuk berusaha untuk meningkatkan kemampuan mendengarkan mereka dan menemukan kosa kata baru, serta kecepatan dan pemahaman pengucapan. Selain itu, memberikan audio dan gambar di YouTube membuat pembelajaran lebih menarik dan memungkinkan siswa untuk menghafal kata atau frasa yang mereka dengar. Nampaknya motivasi siswa dalam belajar menyimak menggunakan youtube dipengaruhi oleh faktor motivasi intrinsik dan ekstrinsik
\end{abstract}

Kata Kunci: Motivasi intrinsik, Motivasi Ekstrinsik, Keterampilan Mendengarkan, YouTube

\section{Introduction}

Motivation is the motivation to start learning a foreign language and then it becomes the driving force to maintain a long and often tedious learning process. Without sufficient motivation, even individuals with the most extraordinary abilities cannot achieve long-term goals, and appropriate curricula and good learning also do not support student achievement. According to Garner and Lambbert (1972) as cited in (Dörnyei, 1998) mentions that although language talent is largely individual variability in language learning 
achievement, motivational factors can affect talent. According to Dörnyei, 2005 as cited in (Lee \& Lin, 2019), motivation has long been recognized as an important component that stimulates language acquisition, as well as an important predictor of eventual success. However, the role of the teacher in the learning process is also very important as a facilitator and motivator for students as explained by Dornyei, (2002) as cited in (Goctu, 2017) which states that enthusiasm, commitment, and persistence of learners are the main determinants of success or failure. This study aims to identify students learning to listen using YouTube which is influenced by intrinsic motivation factors (desire to learn) and extrinsic motivation factors (personal benefits, rewards). This research has previously been carried out (Goctu, 2017), but the author re-examines it in depth with a focus on the media that influences students' listening learning and with different approach methods.

\section{Motivation in Learning Language}

Motivation is a cause of a person's great desire to learn. Teachers and academics have universally acknowledged motivation as one of the major variables determining the degree and success of second/foreign language (B2) learning. The components that affect L2 motivation are Intrinsic and Extrinsic Motivation. According to Deci and Ryan as cited in (Dörnyei, 1998) arguing that intrinsic motivation has the potential to be a central motivator or educational process "Intrinsic motivation is evident whenever students' natural curiosity and interest energize their learning...". Regarding Dornyei's theory, the theory of intrinsic motivation according to (Deci and Ryan, 1985; Ryan and Deci, 2000; Ushioda, 1996; Ushioda, 2003) as cited in (Nicholson, 2013) that intrinsic motivation finds its basic principle on the assumption that humans are active beings who need autonomy and innate curiosity. know. Where this intrinsic motivation is present when students actively seek and participate in activities without having to be rewarded with materials or activities outside of learning assignments. Intrinsic motivation focuses on tasks that are rewarding in and of themselves, such as the pleasure of learning and playing games. According to Dornyei (199a: 275) as cited in (Nicholson, 2013) that extrinsic motivation refers to the behavior that individuals do to receive some extrinsic rewards such as getting good grades, being praised by the teacher or avoiding punishment. With regard to the previous theory, according to Noels (2003) as cited in (Nicholson, 2013) that this type of motivation has some similarities to external goals (personal benefits, rewards, etc.).

\section{Listening Skills}

Listening is an important English competency. Listening does not give passive attention to what is being said but more than that, we must be active to get meaning from the language. The definition of listening according to Vandergift (1999) as cited in (Silviyanti, 2014) is a "complex active process" in which listeners must distinguish between sounds, understand vocabulary and grammatical structures, interpret stress, and intonation, and interpret more broadly. socio-cultural context. great speech context. This can be called listening comprehension, namely knowing speech, understanding the meaning of individual words, and understanding sentence syntax (Ndig, 2013 as quoted in Pourhosein Gilakjani \& Saburi, 2016) as cited in the journal (Ahmadi, Seyedeh, 2016). Learning listening comprehension is assumed to be a more important place in the teaching and learning process of a foreign language, and is one of the most difficult tasks of a language learner. This affects students' motivation in learning listening. ICT has a huge impact on society and affects all aspects of human beings in today's era. This makes ICT have an important role in the teaching and learning process. According to (Cradler \& Bridgforthe 2002; UNESCO, 2004) as cited in (Lawrence \& Tar, 2018) that the role of ICT in teaching and learning has been seen as important among educators as a 
mechanism for improving quality in the classroom, interactivity and facilitating, flexibility in learning experiences anywhere and anytime according to needs. individuals who give them greater freedom and features of lifelong learning. The use of ICT can help students connect and collaborate with other students around the world.

\section{YouTube as Media Motivation}

Learning needs currently requires technology such as using applications with internet connection support, for example, the zoom application, google meet, google classroom, youtube and others. The existence of educational technology and self-produced videos posted on YouTube also makes teaching more interesting. In addition, according to Agazio \& Buckley (2009) as cited in (June et al., 2014) mentioning that YouTube is also used to describe theoretical content, engage students, and inspire innovative teaching methods. YouTube videos have been shown to have a positive effect on teaching and learning across a wide range of disciplines. The appeal of video in teaching comes from the combination of images and sound it produces. Thus, it will be able to produce influential media by teachers or lecturers to help explain the concept of material without meeting face to face. The benefits of YouTube according to Fleck et al (2014) as cited in (Al-Bahrani et al., 2015) stated that YouTube is useful for students as a learning tool as well as being an effective tool for teaching general skills and assignments informal settings or at home. Berk, (2009) as quoted in (Kurniawati, 2013) mentions that using YouTube videos informatively is also useful for describing a concept, presenting alternative points of view, stimulating learning activities, and motivating students. Thus, this video can be used to inspire or motivate students to learn so that students enjoy the material.

\section{Method}

The qualitative case study method was used in this study to analyze the factors that influence students' motivation to learn listening on YouTube. A qualitative case study approach is used for this research because through this approach, the behavior and experiences of each student can be examined and understood better and more deeply. Qualitative researchers attempt to comprehend phenomena by concentrating on the big picture rather than breaking it down into components. According to Creswell \& Brown (1992), qualitative researchers view social phenomena holistically. Why does qualitative study describe it as a street, micro-analyzed panoramic view, The more complex, interactive, and contain a narrative, the better the qualitative study. Visual models of many aspects of a process or central phenomena aid in constructing this holistic picture. This research method uses case studies are specific examples that are often designed to illustrate more general principles, as said by Robson, (2002) as cited in (Mnion \& Morrison, 2007) mention that Case studies prefer analytic generalizations over statistics, i.e. They develop theories that can help researchers to understand cases, phenomena, or other similar situations. Case studies can apply cause and effect, this becomes one of the strengths in their research and they can observe effects in real contexts, recognizing that context is a strong determinant of cause and effect. Questionnaires and interviews were used to collect data. Students majoring in English education at the University of Singaperbangsa Karawang are handed questionnaires in the second, fourth, and sixth semesters. In addition, the authors interviewed 3 students after the students filled out the questionnaire. The interview consisted of 25 questions. Furthermore, the researchers conducted a questionnaire analysis and interviews using the thematic analysis framework developed by Braun \& Clarke (2006) as cited in (Heriyanto, 2018).

\section{Finding and Disscussion}

In obtaining information, researchers asked questions through questionnaires and 
interviews. The following is a questionnaire with 8 participants. In this section, the authors analyze the questionnaires and interviews with thematic analysis techniques. The researcher analyzed the statement into a percentage chart through a questionnaire that had been filled out by students.

The results of this study indicate the factors that influence students' intrinsic and extrinsic motivation to learn to listen using Youtube. Explained about Motivation of to learn listening using YouTube, Students' feelings after using YouTube and Students' Feelings of satisfaction using YouTube for intrinsic Motivation. YouTube as Learning support facilities students, Students enthusiasm in YouTube to learn listening and Students' Difficult using YouTube for extrinsic motivation.

1. The Factor of Intrinsic Motivation

a. Students' Motivation of to learn listening using YouTube.

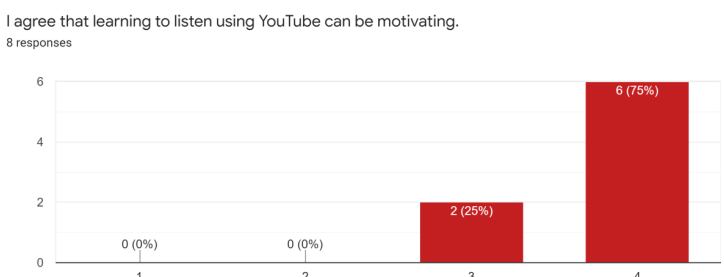

Chart 1.1 : Students' Motivation of to learn listening using YouTube.

Based on the chart above, the authors found that students agreed with the statement about Students enthusiasm in YouTube to learn listening. The statement shows that 6 respondents strongly agree and 2 respondents agree with "I agree that learning to listen to using YouTube can be motivating.". This is reinforced by student answers during interviews. The following is an example of interview excerpts from participants showing their positive perception of Students' Motivation of learning listening using YouTube.

"Of course it can motivate, where in terms of the pronunciation of the conversation delivered by native speakers in the video and there is an image, it certainly trains the spoken vocabulary. With the habit of watching YouTube with the selection of channels that relate to ourselves, it can motivate us to study and in the future, of course we will look more for channels that appear on the panel and relate to what we have watched. So we are curious and of course the knowledge we get we can learn." (S.6.1.20)

"very possible because it adds a new sentence for us," (S.4.20)

"If it's to motivate learning again for sure. But if, for example, the spirit is in high spirits, it will definitely continue to watch." (S.2.20)

Based on students' answers, that students feelings Motivate to learn listening using YouTube. According to participants, YouTube can motivate students to learn listening because the selection of channels that relate to ourself can make us curious to keep watching and feel very motivated by learning to use YouTube because it can add new sentences. The result Relate to theories (Berk 2009) as cited in (Kurniawati, 2013) mentions that utilizing YouTube videos in an informative manner is also beneficial for illustrating a concept, presenting an aternative viewpoint, stimulating a learning activity, and motivating the students.

b. Students' feelings after using YouTube

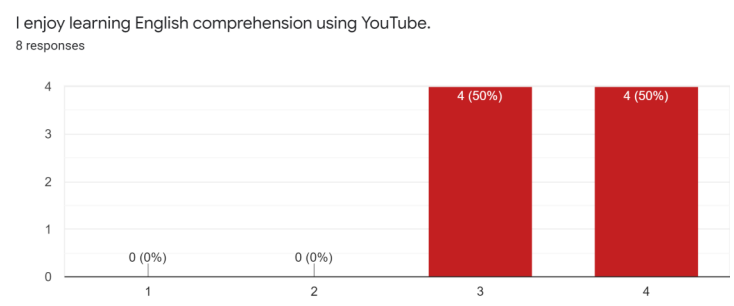

Chart 1.2 : Students' feelings after using YouTube 
"I'm more excited because access to the application is easy, even though what we face are advertisements on YouTube." (S.6.1.9)

"First, add insight. Second, we are getting bolder in speaking English because we know how to pronounce a word." (S.4.9)

"After watching a movie or video on YouTube without subtitles, we feel used to it and it's easy to understand. Then if I watch it and there are words that Alief doesn't know, write down the vocabulary first. So because I'm used to watching YouTube videos, it's good and I understand." (S.2.9)

Based on students' answers, YouTube is effective in helping students learn to listen. According to the first participant, using YouTube made him feel excited to learn listening because the application access was easy to use. But when the video is playing sometimes ads appear but that doesn't make his enthusiasm decrease. The second participant, learning to listen using YouTube can add insight and feel more courageous to interact with friends using English. While the third participant felt accustomed to learning to listen using YouTube and was young to understand what was said by native speakers. Responding to the same question, one of the participants admitted that they used to take notes if they found new vocabulary while listening and recall new vocabulary. The result Relate to theories Fleck (2014) as cited in (Al-Bahrani et al., 2015) states that YouTube is useful for students as a learning tool as well as being an effective tool teaching general skills and tasks in a formal or at home setting.

c. Students' Feelings of satisfaction using YouTube

Below are sample quotes from students indicating their positive reaction to learn to listen using YouTube.

"From my experience that I've tried, it turns out that learning to use YouTube to improve listening is very helpful. But honestly during my experience, I didn't open the Translation setting from YouTube. I listened to Pronounciation and then I studied it again and it was very satisfying. Where I feel challenged because there are new vocabulary that is spoken very quickly and Pronunciation that comes from British or American native speakers which is very fast. Because it can train focus on pronouncing from the native speaker." (S.6.1.18)

"I think using YouTube as a listening lesson is a very satisfying thing for learning. Where there are many interesting things that I can take such as examples of interesting materials and then clear and understandable sound. In my opinion, I am very satisfied with learning to listen using YouTube." (S.4.18)

“"very satisfied.".” (S.2.18)

Based on students' answers, it shows that students are satisfied with using it to learn to listen. According to the first participant, students feel satisfied using YouTube because YouTube can improve their listening, feel challenged in native speaker pronunciation, and he feels YouTube can train their focus on pronouncing from the native speaker. According to the second participant, students were satisfied using YouTube because the materials on YouTube were interesting and the native speaker's pronunciation was clear. The third participant, students feel very satisfied in using YouTube to learn to listen. The result Relate to theories Terantino, (2011) mentions that YouTube offers fast and fun access to language and culture-based videos and instructions from around the world.

2. The Factor of Extrinsic Motivation

a. YouTube as Learning support facilities students.

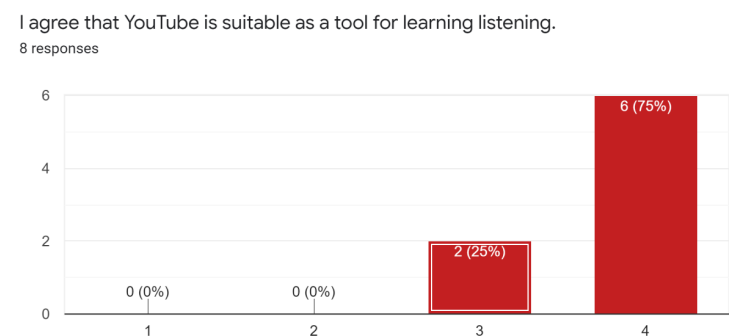


Chart 2.1: YouTube as Learning support facilities students.

Based on the chart above, the writer finds that students agree with the statement about YouTube is Suitable as a tool for learning listening. The statement shows that 6 respondents strongly agree and 2 respondents agree with "I agree that YouTube is Suitable as a tool for learning listening". This is reinforced by students' answers during interviews. The following is an example of interview excerpts from participants showing their positive perception of YouTube as learning support facilities students.

"Yes, depending on the context, for example, if you want to open the TOEFL question and have a discussion. Then listen to the news. Even though it's basic, I'll meet you about the TOEFL unconsciously, maybe that's my opinion." (S.6.1.4)

"In my opinion, it is very suitable because there is a broad factor, yes. So not only native speakers but also other people who speak English. So we can add more vocabulary and we can compare our pronunciation with native speakers and nonnative speakers so we can know what the pronunciation is better." (S.4.4).

"It is very suitable because there are so many content creators from several countries and from one country there are also many who make content about listening skills and others. It's really helpful for people who want to learn English whether it's people who are still in college, still studying at school. From the YouTube platform, there are already so many on every smartphone, laptop and no need to pay if you want to watch, only from the quota to watch videos. The rest don't need courses or take lessons, they can be self-taught." (S.2.4)

Based on the interview transcript above, it was found that participants agreed that YouTube as learning support facilities students to learn listening skills. According to participants, YouTube is a supporter of student learning for toefl exercises and discussions so that they are familiar with toefl questions and YouTube is also a factor in which the source is wide with content creators from various countries. The result Relate to theories Tomlison, 1998 as cited in (Ratmo, 2018) argues that learning materials should be developed to assistt Second Language (L2) students to use visualisation to enhance their undersatnding of the material, to engage them with the materials, to improve retention and to facilitate language acquisition.

b. Students enthusiasm in YouTube to learn listening.

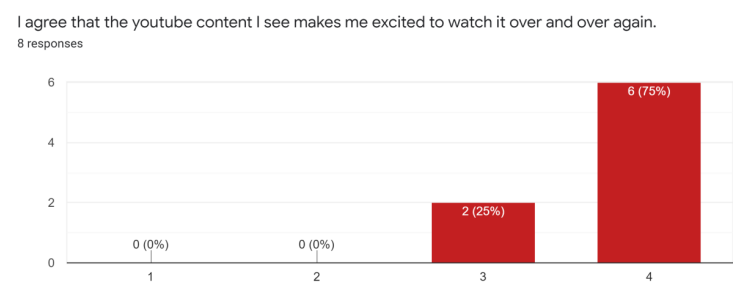

Chart 2.2 : Students enthusiasm in YouTube to learn listening.

Based on the chart above, the authors found that students agreed with the statement about Students enthusiasm in YouTube to learn listening. The statement shows that 6 respondents strongly agree and 2 respondents agree with "I agree that the youtube content I see makes me excited to watch it over and over again.". This is reinforced by student answers during interviews. The following is an example of interview excerpts from participants showing their positive perception of Students enthusiasm in YouTube to learn listening

"To be more precise, the analysis is even more exciting for me. So that makes it a really great challenge for me." (S.6.1.10).

"Yes, very excited." (S.4.10)

"Yes, of course, sometimes it depends on the content they provide if Alief feels happy. Alief will watch other content again." (S.2.10)

Based on students' answers, the enthusiasm of students learning listening using 
YouTube resulted in good enthusiasm. According to participants, using YouTube made them feel excited and challenged in learning to listen. But other participants. Feeling sometimes Enthusiastic about YouTube because it depends on whether the content relates to the mood. The result Relate to theories Rosenfeld, (2007) mentions that learning needs to be motivated, unlike traditional audio-based methods, YouTube videos can make students more interested and active in learning.

Based on the findings, is completing the interviews and questionnaires, the results showed that the factors that influenced students' motivation to learn listening skills using YouTube came from intrinsic motivation and extrinsic motivation. Where the intrinsic motivation factor comes from the interest or curiosity of students to learn is very high. This factor has a long-term impact on students, so students' motivation for their desire to learn is very good. While extrinsic factors come from enthusiasm, learning support facilities, and the environment. Where students feel enthusiastic about using YouTube to learn to listen because YouTube provides a lot of unlimited information and authentic resources. According to Kelsen (2009) as cited in (Ayu, 2016), listening to using YouTube makes learning itself interesting. Another extrinsic motivation factor comes from learning support facilities, in studying learning support facilities it is very important to learn to listen. Learn to listen to the audio to hear but with YouTube, students can learn to listen and see pictures. This is what makes YouTube a learning support facility. This is supported by research by Oddone (2011) as cited in (Ayu, 2016) which states that YouTube has characteristics that make it a good site to use in improving students' listening comprehension. YouTube provides audio and visuals to students with the aim of knowing the sayings or words they hear when studying the subject of the content. The last extrinsic motivation factor that affects students is environmental factors, where the main environmental factor in the environment is using YouTube for entertainment, students will feel it is not just entertainment but becomes new knowledge that can be found on YouTube. The results of this study are factors of intrinsic and extrinsic motivation that can affect students learning to listen to using YouTube.

\section{Conclusion}

The main objective of this research is to identify Students' Motivation in Learning Listening using YouTube. The findings reveal that students agree to use YouTube for listening learning because YouTube has material that is useful for them, provides an understanding of their language, is interesting, improves listening, and they feel motivated to use YouTube to learn to listen. However, there are some students who are less motivated to learn to listen using YouTube at home. This is because without an instructor guiding the learning process, students find it difficult to understand the material. The media will support student learning, but if there is no instructor in the learning process, it will make learning that is not satisfied in class achieved. Some of the reasons for this are obtained from their written answers such as when using YouTube. Another difficulty is in the network connection which is sometimes down. The next finding is the efforts of teachers/lecturers to motivate listening learning, namely researchers and educators in providing media according to students' learning conditions so that student's motivation to learn listening that already exists in them is not lost. By providing material using YouTube and having to sort 
out content that is tailored to the student's learning needs, it can affect their motivation and adjust their level.

\section{References}

Ahmadi, Seyedeh, M. (2016). The Importance of Listening Comprehension in Language Learning. International Journal of Research in English Education, 1(1), 7-10. http://ijreeonline.com/browse.php?a_c ode $=$ A-10-1-2\&

Al-Bahrani, A., Patel, D., \& Sheridan, B. (2015). Engaging students using social media: The students' perspective. International Review of Economics Education, 19, 36-50. https://doi.org/10.1016/j.iree.2015.06. 001

Ayu, L. P. (2016). YouTube Videos in Teaching Listening: The Benefits in Experts' Views. Research in English and Education (READ), 1(2), 152160.

http://www.jim.unsyiah.ac.id/READ/a rticle/view/2584

Dörnyei, Z. (1998). Motivation in second and foreign language learning. Language Teaching, 31(3), 117-135. https://doi.org/10.1017/S02614448000 1315X

Goctu, R. (2017). The Effects of Motivation on Listening Skills of ELT Students in Georgia (IBSU Case). Smart Moves Journal Ijellh, 4(5), 15. https://doi.org/10.24113/ijellh.v4i5.13 42

Heriyanto, H. (2018). Thematic Analysis sebagai Metode Menganalisa Data untuk Penelitian Kualitatif. Anuva, 2(3), 317.

https://doi.org/10.14710/anuva.2.3.317 $-324$

June, S., Yaacob, A., \& Kheng, Y. K. (2014). Assessing the use of youtube videos and interactive activities as a critical thinking stimulator for tertiary students: An action research.

International Education Studies, 7(8), 56-67.

https://doi.org/10.5539/ies.v7n8p56

Kurniawati, D. (2013). the Effectiveness of Using Youtube Video in Teaching. 1, 52-65.

Lawrence, J. E., \& Tar, U. A. (2018). Factors that influence teachers' adoption and integration of ICT in teaching/learning process. Educational Media International, 55(1), 79-105. https://doi.org/10.1080/09523987.2018 .1439712

Lee, T. S. O., \& Lin, S. Y. (2019). English teachers' uses of motivational strategies beyond an established framework. Educational Research, 61(4), 451-468. https://doi.org/10.1080/00131881.2019 .1677170

Mnion, L., \& Morrison, K. (2007). Research Methods in. In Education And Training (Issue August).

Nicholson, S. J. (2013). Influencing Motivation In The Foreign Language Classroom. Journal of International Education Research (JIER), 9(3), 277286. https://doi.org/10.19030/jier.v9i3.7894

Ratmo. (2018). Youtube Media : A Challenge to Develop Grammar Learning Activities. Proceeding Humanis Universitas Pamulang, 298310.

http://openjournal.unpam.ac.id/index.p $\mathrm{hp} /$ Proceedings/article/view/2980

Silviyanti, T. M. (2014). Looking into EFL students' perceptions in listening by using English movie videos on YouTube. Studies in English Language and Education, 1(1), 42. https://doi.org/10.24815/siele.v1i1.111 9

\section{About the Author(s):}


Jurnal Edumaspul, 5 (2), Year 2021 - 790 (Umi Quina Indah Wati Poeryono ${ }^{1}$, Yousef Bani Ahmad ${ }^{2}$, Sidik Indra Nugraha)

${ }^{1}$ Umi Quina Indah Wati Poeryono is an English Education student from Singaperbangsa University of Karawang.

${ }^{2}$ Yousef Bani Ahmad is a lecture in Faculty of Teachers Training and Education of
Singaperbangsa University of

Karawang.

${ }^{3}$ Sidik Indra Nugraha is a lecture in Faculty of Teachers Training and Education of Singaperbangsa University of Karawang 